\title{
MANFAAT BUAH MURBEI SEBAGAI TERAPI ADJUVAN OBESITAS
}

\author{
Kurnia Hadi Saputra*, Muhammad Alka Fakhrizal \\ Fakultas Kedokteran, Universitas Lampung, Jl. Prof. Dr. Ir. Sumantri Brojonegoro No.1, Gedong \\ Meneng, Kec. Rajabasa, Kota Bandar Lampung, Lampung, Indonesia 35145 \\ *kurniahadisaputra55@gmail.com (+6287796556555)
}

\begin{abstract}
ABSTRAK
Obesitas adalah gangguan kesehatan kompleks yang disebabkan oleh peningkatan berat badan sebagai akibat dari peningkatan massa jaringan adiposa, hal ini disebabkan tidak seimbangannya antara asupan dan energi yang digunakan. Obesitas dapat menjadi dasar dari penyakit kronik lain seperti aterosklerosis yang menyebabkan penyakit jantung koroner, darah tinggi, diabetes melitus tipe 2 dan lainnya. Murbei mengandung komponen bioaktif yang baik dalam menurunkan lemak dan mencegah obesitas. Tujuan dari tinjauan pustaka ini adalah untuk melaporkan temuan ilmiah terbaru tentang peran kandungan murbei dalam mencegah obesitas dengan kandungan kaya antosianin, fenolik, dan antioksidan yang dapat menurunkan kadar lemak di tubuh. Metode yang digunakan dalam artikel berjenis tinjauan pustaka ini adalah literature searching method melalui database NCBI dan Google Scholar. Tahun penerbitan sumber pustaka adalah dari tahun 1997 sampai tahun 2019 dengan 23 sumber pustaka dan 14 sumber yang dapat digunakan. Tema yang dikumpulkan terkait dengan kandungan murbei dalam mencegah obesitas. Hasil dari sintesis artikel yang telah ditemukan yaitu murbei bermanfaat sebagai terapi adjuvan dalam mencegah dan mengobati obesitas.
\end{abstract}

Kata kunci: antiobesitas, antosianin, morus alba

\section{THE BENEFIT OF MULBERRY AS ADJUVANT THERAPY FOR OBESITY}

\begin{abstract}
Alopecia means hair loss regardless of the type of cause. Alopecia can be divided into two main categories: scar tissue (cicatricial) and non-scar tissue (non-cicatricial). Causes of alopecia include aging, malnutrition, hormonal imbalance, illness and stress. One of the plants that has the potential to prevent hair loss is katuk leaves because it is rich in vitamins and phenolic compounds. The purpose of this literature assessment is to report the latest scientific findings about the benefits of katuk leaves in the prevention of hair loss by promoting growth, improving vascularity, and nourishing hair. The method used in this article is this literature is a method of searching literature through the NCBI database and Google Scholar. The year of library resources is from 2001 to 2020 with 32 library sources and 20 usable sources. The theme collected is related to the katuk leaf collection in the prevention of hair loss or alopecia. As a result of the synthesis of articles that have been found, katuk leaves are useful in preventing hair loss.
\end{abstract}

Keywords: antiobesitas, antosianin, morus alba

\section{PENDAHULUAN}

Obesitas adalah kondisi menumpuknya lemak secara berlebihan akibat tidak seimbangnya asupan energi dengan energi yang digunakan dalam jangka waktu yang lama sehingga meningkatkan berat badan (WHO, 2000). Obesitas dikenal sebagai gangguan kesehatan kompleks yang disebabkan oleh peningkatan berat badan sebagai akibat dari peningkatan massa jaringan adiposa yang timbul dari 
jumlah ukuran sel-sel lemak yang lebih tinggi dan lebih besar (Otto \& Lane, 2005).

Hampir sepertiga orang dewasa dan sekitar 17\% remaja di Amerika Serikat mengalami obesitas. Menurut Pusat Pengendalian dan Pencegahan Penyakit (CDC), data 2011 hingga 2012, satu dari lima remaja, satu dari enam anak usia sekolah dasar, dan satu dari 12 anak usia prasekolah mengalami obesitas (Kiran, 2019). Prevalensi obesitas di Indonesia berdasarkan indikator RPJMN terdapat sekitar $15,4 \%$ mengalami obesitas dengan IMT 27 pada tahun 2015-2019. Pada orang dewasa dengan usia 18 tahun ke atas terdapat sekitar 28,7\% dengan IMT 25 dan pada anak 5-12 tahun sekitar 10,8\% (PT2PM, 2019)

Obesitas disebabkan oleh banyak faktor yang dapat bersifat genetik, budaya, dan sosial yang dapat dianggap umum. Penyebab lain dari obesitas termasuk berkurangnya aktivitas fisik, insomnia, kebiasaan makanan, gangguan endokrin, obat-obatan, iklan makanan, dan metabolisme energi (Jonathan, 2018).

IMT adalah indikator yang paling sering digunakan dan praktis untuk mengukur tingkat populasi berat badan lebih dan obesitas pada orang dewasa. Klasifikasi obesitas berdasarkan IMT menurut kriteria Asia Pasifik dikatakan obesitas jika lebih dari sama dengan 25 ke atas. Yaitu 25-29,9 untuk obesitas tingkat I, dan diatas 30 untuk obesitas tingkat II. (WHO, 2006).

Obesitas dikaitkan dengan penyakit kardiovaskular, dislipidemia, dan resistensi insulin, pada gilirannya, menyebabkan diabetes, stroke, batu empedu, hati berlemak, sindrom hipoventilasi obesitas, sleep apnea, dan kanker. Ada peningkatan studi bahwa obesitas perut dan penumpukan lemak tubuh memainkan peran penting dalam patogenesis gangguan tersebut (Jonathan, 2018).

Ada beberapa strategi pengobatan untuk mengatasi obesitas yaitu dengan cara mengurangi asupan makanan, menghambat penyerapan nutrisi (terutama lemak), meningkatkan termogenesis, memodulasi lemak dengan mengatur sintesis lemak atau lipolisis, diferensiasi adiposa atau apoptosis dan memodulasi pengontrol pusat yang mengatur berat badan (Bray \& Tartaglia, 2000). Untuk itu dibutuhkan diet dari makanan yang dapat menurunkan lemak dengan sedikit efek samping yaitu yang berasal dari tumbuhan.

Murbei (Morbus alba) adalah tumbuhan yang berasal dari Cina dan dapat dibudidayakan pada iklim daerah tropis dan subtropis. Buah murbei memiliki beberapa sifat farmakologis yang potensial termasuk efek anti-kolesterol, anti-diabetes, antioksidan dan antiobesitas. Sifat farmakologis ini disebabkan oleh adanya senyawa polifenol termasuk antosianin, namun, warna yang berbeda dari buah murbei bahkan dari spesies yang sama mungkin memiliki jumlah antosianin yang berbeda (Gerasopoulos, 1997). Buah murbei memiliki efek hipolipidemik karena buah murbei memiliki kandungan serat dan asam linoleat yang tinggi (Yang, 2010). Tujuan dari tinjauan pustaka ini adalah mengetahui kandungan buah murbei sebagai terapi adjuvan dalam mencegah dan mengatasi obesitas. 


\section{METODE}

Metode yang digunakan adalah literature searching. Sumber pustaka yang digunakan dalam artikel ini berjumlah 23 pustaka dan 14 jurnal yang dipakai dalam review manfaat buah murbei terhadap obesitas, baik yang berasal dari buku, jurnal nasional atau internasional, maupun website. Penelusuran sumber pustaka dalam artikel ini melalui database NCBI dan Google Scholar dengan kata kunci Morus alba, antiobesity, anthocianin Pemilihan artikel sumber pustaka dilakukan dengan melakukan peninjauan pada judul dan abstrak yaitu membahas tentang potensi buah murbei dalam mencegah dan mengobati obesitas. Tahun penerbitan sumber pustaka dalam penulisan artikel ini adalah 19917 hingga tahun 2019.

\section{HASIL}

Penelitian Lim et al. (2013) melaporkan bahwa tikus obesitas yang diinduksi diet tinggi lemak yang diberi kombinasi ekstrak daun murbei dan ekstrak buah murbei pada dosis rendah dan tinggi mengalami penurunan yang signifikan dalam kenaikan berat badan, glukosa plasma puasa, penilaian model insulin dan homeostasis dari resistensi insulin.

Murbei telah diidentifikasi kaya akan anthocyanin, termasuk sianidin-3glukosida, sianidin-3-rutinoside, pelargonidin-3 glukosida, dan pelargonidin-3-rutinoside. Dalam laporan sebelumnya, menunjukkan bahwa memberi makan anthocyanin murni dapat mengurangi berat badan dan lemak tubuh tikus yang diberi makan dengan diet tinggi lemak (Prior et al., 2009).

Aktivitas hipolipidemik serbuk keringbuah murbei juga diuji pada tikus Wistar hiperlipidemia yang diinduksi menggunakan diet tinggi lemak. Serbuk ini secara efektif mengurangi trigliserida serum (TG), kolesterol total (TC), kolesterol LDL, dan indeks aterogenik tetapi meningkatkan serum kolesterol lipoprotein densitas tinggi serum (Yang et al., 2010).

Sementara efek penurun lipid dari ekstrak air murbei (Morus alba L.) yang mengandung polisakarida dan molekul bioaktif lainnya diselidiki secara in vivo pada hamster. Efek hipolipidemik ekstrak air murbei mampu menstimulasi ekspresi gen LDLR dan kemampuan pembersihan LDL serta pada penghambatan biosintesis lipid (Liu et al., 2009).

\section{PEMBAHASAN}

Obesitas bisa disertai dengan gangguan metabolisme lain seperti dislipidemia, hiperglikemia, dan hipertensi. Beban obesitas sebagian besar berasal dari penyakit kronis yang berhubungan seperti penyakit kardiovaskular, penyakit paru-paru, darah tinggi, dan diabetes mellitus tipe II (Adam et al, 2016). Meskipun ada sejumlah obat yang disetujui untuk pengobatan penderita obesitas, namun pengobatan tersebut memiliki beberapa efek samping yang parah seperti penyakit jantung dan gangguan kejiwaan (Garrow, 2010). Sementara itu, penelitian terbaru menunjukkan bahwa mengkonsumsi komponen bioaktif yang berasal dari tumbuhan mengandung tinggi senyawa fenolik dapat mengurangi risiko obesitas dan penyakit kronis dengan toksisitas yang rendah (Cefalu, 2008). Untuk itu diperlukan diet baru berdasarkan berbagai komponen bioaktif dalam tumbuhan sebagai intervensi terhadap obesitas.

Salah satunya adalah buah murbei. Tanaman murbei (genus Morus, 
keluarga Moraceae) tersebar luas di daerah tropis dan subtropis yang berasal asli dari Cina. Biasanya daun dari tanaman murbei dimanfaatkan sebagai makanan untuk ulat sutera sedangkan buah murbei sendiri sedikit mendapat perhatian dan jarang dimanfaatkan (Pérezgregorio et al., 2011).

Buah murbei mengandung banyak protein, lipid, karbohidrat, serat, mineral, dan vitamin tetapi rendah kalori. Buah ini juga mengandung antosianin yang telah menerima banyak perhatian karena berbagai efek biologisnya, termasuk antitumor, antioksidan, dan aktivitas antidiabetes. Selain itu, buah murbei juga menyediakan vitamin lain, seperti tiamin, riboflavin, niasin, folat, vitamin A, vitamin B-6, vitamin E, dan vitamin K. Empat tokoferol terdeteksi dalam buah murbei (Yang et al., 2010).

Antosianin, yang termasuk dalam famili flavonoid, adalah pigmen yang larut dalam air yang bertanggung jawab atas sebagian besar warna buah dan sayuran merah, biru, dan ungu serta jaringan atau produk tanaman lainnya. Antosianin, serta fitokimia tanaman, memainkan beberapa fungsi yang beragam, tetapi kegiatan utamanya adalah melindungi tanaman dari risiko oksidatif yang ditimbulkan oleh berbagai stresor lingkungan (sinar matahari dan agen lingkungan lainnya) dan melindungi tanaman dari infeksi jamur, bakteri, atau virus. Antosianin dikenal sebagai senyawa yang dapat memodulasi mekanisme homeostasis glukosa, lipid, dan asam amino dan menekan peradangan. Antosianin dapat menyebabkan perubahan pada jaringan adiposa, seperti yang ada pada level ekspresi adipositokin (Azzini, 2016).
Stres oksidatif adalah faktor penyebab yang menghubungkan hiperlipidemia dengan patogenesis aterosklerosis yang berhubungan erat dengan penderita obesitas. Stres oksidatif terjadi ketika produksi radikal bebas melebihi kapasitas sistem antioksidan alami. Selama metabolisme kolesterol, ia dikirim ke hepatosit, di mana sejumlah besar spesies oksigen reaktif dihasilkan. Oleh karena itu, diet tinggi lemak menyebabkan peningkatan produksi radikal bebas, yang meningkatkan peroksida lipid (Harrison et al., 2003).

Flavonol utama dalam buah murbei adalah rutin, morin, quercetin dan myricetin. Keempat flavonol ini dilaporkan sebagai antioksidan yang efektif ( $\mathrm{Lu}$ et al., 2006). Analisis komponen antioksidan pada penelitian lain juga menunjukkan bahwa selain anthocyanin dan flavonoid, murbei juga mengandung total fenolat $(2,3 \%)$, resveratrol $(0,03 \%)$, vitamin $\mathrm{C}(0,12 \%)$ dan rendahnya tingkat vitamin $\mathrm{E}$ $(0,032 \%)$ yang semuanya merupakan antioksidan alami yang kuat (Toyokuni et al., 2003). Vitamin C tidak hanya antioksidan yang efektif untuk membersihkan radikal bebas, tetapi juga memiliki efek sinergis dengan fenolik. Vitamin C meregenerasi antioksidan fenolik dan meningkatkan kemampuan antioksidannya ketika digunakan bersama (Min, 2003).

Buah murbei mengandung banyak flavonol, termasuk rutin, quercetin, myricetin, dan kaempferol. Buah mulberry juga mengandung beragam asam fenolik. Asam fenolik dalam buah mulberry terutama diwakili oleh asam hidroksisinamat dan turunan asam benzoat (Yuan et al., 2017). Asam linoleat dan asam linolenat adalah asam lemak esensial tak jenuh bagi manusia yang harus diperoleh melalui makanan. 
Mereka sangat penting untuk membentuk membran sel, untuk perkembangan normal sistem saraf pusat, dan untuk sintesis prostaglandin dan metabolisme kolesterol. Mereka juga merupakan konstituen hipolipidemik yang efektif. Asam linoleat diet menurunkan kolesterol plasma pada tikus dengan mempromosikan penyerapan HDL dalam hati, yang dihasilkan dari pengaruh asam linoleat pada komposisi spesies molekul fosfatidilkolin dalam hati dan plasma (Wu, 2003).

Murbei mengandung serat sebesar $24,3 \%$, yang diketahui dapat menurunkan kadar trigliserida dengan menghambat lipogenesis hati, dan menurunkan kolesterol LDL plasma dengan menghambat pembentukan kolesterol dan penyerapan asam empedu serta meningkatkan aktivitas reseptor LDL. Serat makanan $(24,3 \%)$ dan asam linoleat $(5,9 \%)$ relatif tinggi dalam murbei, dan memainkan peran penting dalam efek hipolipidemik (Venkatesan et al., 2003). Efek sinergis antara polisakarida, fenolik, antosianin dan senyawa lain yang terkandung dalam buah murbei bisa menjadi alternatif pencegahan dan pengobatan obesitas dengan menurunkan kolesterol LDL dan mencegah pembentukan lipid.

\section{SIMPULAN}

Buah murbei memiliki komponen bioaktif yang bermanfaat sebagai terapi adjuvan dalam mencegah dan mengobati obesitas.

\section{DAFTAR PUSTAKA}

Adams, K. F., Schatzkin, A., Harris, T. B., Kipnis, V., Mouw, T., BallardBarbash, R., Hollenbeck, A., Leitzmann, M. F. (2006). Overweight, obesity, and mortality in a large prospective cohort of persons 50 to 71 years old. N Engl J Med. Aug 24; 355(8):763-78.

Azzini, E., Maiani, G., Garaguso, I., Polito, A., Foddai, M. S., Venneria, E., Durazzo, A., Intorre F, Palomba, L., Rauseo, M. L., Lombardi-Boccia, G., Nobili, F. (2016). The Potential Health Benefits of Polyphenol-Rich Extracts from Cichorium intybus L. Studied on Caco-2 Cells Model. Oxid Med Cell Longev. 2016:1594616.

Cefalu WT, Ye J, Zuberi A, Ribnicky DM, Raskin I, Liu Z, Wang ZQ, Brantley, P. J., Howard, L., Lefevre, M. (2008). Botanicals and the metabolic syndrome. Am J Clin Nutr. Feb; 87(2):481S-7S.

Garrow, J. S. (2010). Withdrawal of sibutramine. Magic bullets now uncontrolled. BMJ. Mar 10; 340():c1351.

Gerasopoulos, D., Stavroulakis, G. (1997). Quality characteristics of four mulberry (Morus sp) cultivars in the area of Chania, Greece. J. Sci. Food Agric.; 73: 261-264. doi: 10.1002/(SICI)

Harrison, D., Griendling, K., Landmesser, U., Hornig, B., Drexler, H., 2003. Role of oxidative stress in atherosclerosis. Am. J. Cardiol. 91, 7-11.

Jonathan, Q. P. (2018). Definitions, Classification, and Epidemiology of Obesity. Endotext. https://www.ncbi.nlm.nih.gov/boo ks/NBK279167/

Kiran, P. K., Ravi, K. K. (2019). Obesity.

Statpearl. 
https://www.ncbi.nlm.nih.gov/boo ks/NBK459357/

Lim, H. H., Lee, S. O., Kim, S. Y., Yang, S. J., Lim, Y. (2013). Antiinflammatory and antiobesity effects of mulberry leaf and fruit extract on high fat diet-induced obesity. Exp Biol Med (Maywood). Oct; 238(10):1160-9.

Lu, Y., Wang, L., Wei, H., Yang, Z.Q., Wang, W., 2006. Structureactivity relationship of flavonoids in antioxidant activity. Food Sci. 27 (12), 233-237.

Lim, H. H.; Lee, S. O.; Kim, S. Y.; Yang, S. J.; Lim, Y. (2013). Antiinflammatory and antiobesity effects of mulberry leaf and fruit extract on high fat diet-induced obesity. Exp. Biol. Med., 238, 1160- 1169

Liu, L. K., Chou, F. P., Chen, Y. C., Chyau, C. C., Ho, H. H., \& Wang C. J. (2009). Effects of mulberry (Morus alba L.) extracts on lipid homeostasis in vitro and in vivo. Journal of Agricultural and Food Chemistry, 57, 7605-7611.

Venkatesan, N., Devaraj, S.N., Devaraj, H., 2003. Increased binding of LDL and VLDL to apo B, E receptors of hepatic plasma membrane of rats treated with fibernat. Eur. J. Nutr. 42, 262271.

Min, J.Q., 2003. Food Chemistry. China Agricultural University Press, Beijing. p. 124

Prior, R. L., Wu, X., Gu, L., Hager, T.; Hager, A., Wilkes, S., Howard, L. (2009). Purified berry anthocyanins but not whole berries normalize lipid parameters in mice fed an obesogenic high fat diet. Mol. Nutr. Food Res., 53, 1406-1418.

Sudoyo, A. W. (2009). Buku Ajar Ilmu Penyakit Dalam, jilid II, edisi V. Jakarta: Interna Publishing.

Toyokuni, S., Tanaka, T., Kawaguchi, W., Fang, N.R., Ozeki, M., Akatsuka, S., Hiai, H., Aruoma, O.I., Bahorun, T., 2003. Effects of the phenolic contents of Mauritian endemic plant extract on promoter activities of antioxidant enzymes. Free Radic. Res. 37, 1215-1224

WHO. (2000). Obesity: preventing and managing the global epidemic. Reporton a WHO Consultation on Obesity, Geneva, 3-5June, 1997.WHO/NUT/NCD/98.1.

Technical

Wu, K., 2003. Nutrition and Food Hygiene. People's Health Publishing House, Beijing. p. 21.

Yang, X., Yang, L., Zheng, H. (2010). Hypolipidemic and antioxidant effects of mulberry (Morus alba L.) fruit in hyperlipidaemia rats. Food Chem Toxicol. Aug-Sep; 48(8-9):2374-9.

Yuan, Q., \& Zhao, L. (2017). The Mulberry (Morus alba L.) FruitA Review of Characteristic Components and Health Benefits. Journal of Agricultural and Food Chemistry, 65(48), 10383-10394.

Yang, X. L., Yang, L., Zheng, H. Y. (2010). Hypolipidemic and antioxidant effects of mulberry (Moms alba L.) fruit in hyperlipidaemia rats. Food Chem. Toxicol., 48, 2374-2379. Report Series Number 894.Geneva: World Health Organization, 
Plonka P. M., Handjiski, B., Popik, M., Michalczyk, D., Paus, R. (2005). Zinc as an ambivalent but potent modulator of murine hair growth in vivo- preliminary observations. Exp Dermatol. Nov; 14(11):844-53.

Platel, K., Srinivasan, K. 2017. Nutritional profil of chekumaris, a less explored green leafy vegetable. The Indian Journal of Nutrition and Dietics. Volume 54 Issue 3. https://doi.org/10.21048/ijnd.2017 .54 .3 .15765

Rukmana, R., \& Mukti, I. H. 2003. Katuk: Potensi Dan Manfaatnya. Penerbit Kanisius; Yogyakarta. ISBN 9792106774

Rinaldi, F., Marzani, B., Pinto, D., Sorbellini, E. (2019). Randomized controlled trial on a PRP-like cosmetic, biomimetic peptides based, for the treatment of alopesia areata. J Dermatolog Treat. Sep;30(6):588-593

Rambwawasvika, H., Dzomba, P., and Gwatidzo, L. (2019). Hair Growth Promoting Effect of Dicerocaryum

senecioides Phytochemicals Internation Journal of Medicinal Chemistry. https://doi.org/10.1155/2019/7105 $\underline{834}$

Selvi, V. S., Bhaskar, A. Characterization of antiinflammatory activities and antinociceptive effects of papaverine from Sauropus androgynus (L.) Merr. Global J. Pharmacol., 2012, 6(3), 186-192.

Samad, A.P.A., Santoso, U., Lee, M. C., Nan, F. H. (2014). Effect of dietary katuk on growth nonspecific immune and disease resistance againts vibrio alginolyticus infection in grouper epinephelus coloides. Fish shellfish Immunol. 30; 582-89

Signori, V. (2004). Review of the current understanding of the effect of ultraviolet and visible radiation on hair structure and options for photoprotection. International Journal of Cosmetic Science, vol. 26, no. 4, pp. 219-219.

Susanti, N. M. P. Budiman, I. N. A, Warditiani, N. K. (2014). Skrining fitokimia ekstrak etanol 90\% daun katuk (Sauropus androgynus (L.) Merr.). Jurnal Farmasi Udayana, [S.1.], oct.. ISSN 2622-4607.

Trueb, R. M. (2009). Oxidative stress in ageing of hair. Int $\mathrm{J}$ Trichology.; $1: 6-14$

Varothai, S., Bergfeld, W.F. (2014). Androgenetic alopesia: An evidencebased treatment update. Am J Clin Dermatol;15:217-30

Zito, P. M., Hin, N. (2017). Minoxidil use in alopesia. $\mathrm{J}$ Dermatol Nurses'Assoc;9:264-7. 
Jurnal Penelitian Perawat Profesional, Volume 2 No 2 Hal 201 - 208, Mei 2020 Global Health Science Group 